Rafat PRUSAK

\title{
2.5. ANALYSIS OF SELECTED ASPECTS OF THE IMPACT OF INTELLECTUAL CAPITAL ON INNOVATION MANAGEMENT
}

\begin{abstract}
Summary
Intellectual capital is one of the most important contemporary elements allowing companies to search and build a market advantage. Its range covers almost all tangible and intangible resources of the company. Analysis of the structure allows for a more complete understanding of the relations between the various resources of the company. This makes it possible intensification of the processes leading to the occurrence of synergic effect. An important area which activities in the management of intellectual capital may affect are innovative processes. This requires proper approach to all components of intellectual capita: the relational capital, structural capital, and - above all - human capital. The aim of the research undertaken by the author was trying to analyze some elements related to intellectual capital, which may affect the process of innovation. The study presented in this article was conducted on a sample of 100 companies, of which 50 have implemented some aspects of the intellectual capital management system.
\end{abstract}

Keywords: intellectual capital, innovations, human resource management

\section{Introduction and literature review}

The introduction of the concept of intellectual capital allowed - both theorists and practitioners - a fuller focus of their work, research and analysis related to effectiveness of enterprise operation. Projects related with different threads, seemingly unconnected, could be logically integrate. Information incoming from the projects could be aggregated and allow identification - previously undiscovered or not analyzed, in this context dependencies and relationships. At the same time the concept of intellectual capital has led to a reorientation of methods and techniques of business management as a result of the full emphasize the role of intangibles and pointing them as key factors of success. Concepts related with intellectual capital are undergoing a fairly intensive development and there are fundamental factors stimulating this development, namely: the wider acceptance of the human capital concept (which contributed to the growth of investments in this area), the violent and turbulent market changes (pushing to look for ways to increase the flexibility of the structures and methods of operation relying on intangible resources not subject to rapid devaluation) and the increase in the intensity of the competitive contest (which forces the use of unique knowledge-based methods of building market advantages).

Intellectual capital - despite intensive research - still remains largely unrecognized. The reasons for this should be sought in its construction: multi-layered, complex and 
filled with a number of unclear connections and relationships. This is well illustrated by J. Fitz-Enz (2001), who interpret intellectual capital as a complex combination of processes and culture connected with a network of various relationships and human capital. Such an approach to the problem implies taking into account another important problem hindering the analysis and understanding of intellectual capital, namely the human factor. People are - from the point of view of the development of intellectual capital - the most important resource for organizations: seeking, processing, creating and using knowledge to achieve the strategic objectives and building a market advantage. At the same time, however, as a result of their diversity and unpredictability (positively and negatively) people are very difficult resource to manage. The effective development of intellectual capital requires consideration of such factors as: intuition, interpersonal communication, feelings or desires of the people (Skrzypek, 1999). Extensive analysis of the individual elements of the personnel function in the context of their correlations and relationships with the intellectual capital of an enterprise brings the list of the most important activities, whose results contribute to the development of intellectual capital. Personnel policy and strategy need to be based on the priority of developing valuable human capital and the importance of continuous monitoring of existing solutions to ensure their continuous improvement and optimization. Employment planning should use development path taking into account the needs of both the enterprise and its employees. Preparation of the employment plan should be conducted simultaneously with the determination of the enterprise's demands for knowledge and competence. In area of employee selection it is important not only to attract individuals characterized by the right competence profile, but also to ensure their quick adaptation in the work environment. Proper development of intellectual capital requires the use of appropriate employee assessment procedures enabling the testing of the employees' knowledge, skills, attitudes or degree of adaptation to the applicable rules and norms of organizational culture.

The thorough analysis of the views presented in the literature providing the grounds for the examining the structure of intellectual capital. Commonly accepted theory in the literature, distinguishes three basic components: human capital, structural capital and relational capital.

Interpretation of human capital its difficult due to its both individual and collective character, which might be considered separately. In individual terms, human capital can be defined as an employee's professional potential, whose extent of utilization is dependent on the individual's integration with the enterprise and involvement. It is dependent on the effective connection of the incentive system with the personality traits of an employee, his commitment and professional potential. In context of collective human capital synergic interactions among the potentials of individual workers may lead to achieving extraordinary and unexpected results and performance. Structural capital and its relationship with human capital should be considered in dynamic terms, especially in the context of their interaction. Structural capital of an enterprise is an important factor determining the range and possibilities of actions that can be taken by employees. In area of relational capital particular attention should be 
draw to the elements that make it possible to increase the number of relationships and the strength of ties between the enterprise and entities located in its vicinity.

One of the most important reasons for interest in intellectual capital is building a permanent market advantage. In this context, the intellectual capital can lead to: development of new products, building image of the company, more efficient use of resources, development of plans and strategies which are based on the strengths of the company and market opportunities, strengthening internal and external relations, intensive research and development, etc. (Szara - Pierścieniak, 2007). Managing intellectual capital forces intelligent actions in the enterprise through: implementation of innovations, making creative decisions, conjugated utilization of high-quality knowledge at all levels the organization (Pobrotyn, 2012).

Innovations are one of the most important elements affecting the size and durability of the enterprise market advantage. It should be noted that market advantage can be interpreted and understood in many ways. In simple terms, innovation is everything that is in the minds of customers creates an image of the company or its products and helps differentiate the company from competitors. By using different perspective market advantage is the ability to generate unique competencies and using them to accomplish tasks and processes that are beyond the reach of competitors. Six key processes creating market advantages exists in this broader perspective: strategic investments, building the social image of organization, creating vision of organization, deployment of resources by the actors on the market, defining the success of the organization, shaping the theory of action (Rindova - Fomburn, 1999). It should be noted at this point that none of the market advantages is permanent - competitors' activities, market trends, technological developments and the selling methods contribute to the devaluation of the advantages.

Innovation can be seen as a process of transforming the existing possibilities in the new ideas and putting them into practical use. Begg (1997) describes it as the application of new knowledge in the production process. Schumpeter (1960) It identifies the areas of innovation articulation: the implementation of innovative products, preparation of original production methods, creating of new market, the acquisition of innovative resources or expand existing ones, implementation of new methods of organizing the industry. It is important to emphasize that innovation is a process that occurs in most spheres of human activity. As stated by Drucker (1992) innovation is not an action relating exclusively to the area of science or technology, but also to the evolution of economic and social relationships relates to behaviour of humans occurring in various roles, namely producers, consumers, scientists, ordinary citizens, etc.

\section{Analysis of the results}

The primary objective of the study was an attempt to analyze the basic relationships between the implementation of the company's intellectual capital management mechanisms and innovative processes. The study was conducted using a survey based on a questionnaire with ten questions. Questions covered the following issues: (A) 
activities in conducted works, (B) the sources of knowledge, (C) the key factors of success (D) reasons for innovative ideas, (E) impulses to start the innovation process (F) economic effects, $(\mathrm{G})$ the time of implementation, $(\mathrm{H})$ the involvement of employees, (i) the number of problems encountered (J) time spent on solving problems, $(\mathrm{K})$ the amount of grass-roots initiatives. Moreover, additional analyzes were performed to determine the level of correlation between the analyzed aspects and selected strategic factors. These criteria were: company size (small - less than 50 people, average - from 50 people to 250 people, large - more than 250 people), - the type of business (manufacturing companies or service), the attractiveness of the sector (defined for each sector using universal criteria). The research sample was 100 companies of which 50 had implemented mechanisms of intellectual capital management.

The study allowed the identification of several important trends and phenomena. Above all, it revealed a relationship between the fact of implementation of intellectual capital management mechanisms and: the level of employee involvement in innovation processes, the number of problems encountered during the development and implementation of innovation, number of grassroots initiatives resulting in new solutions (distribution of answers is presented in Figure 1). In each of these cases, the correlation was average (respectively $0.36,0.36,0.33$ ). In this paper to determine the degree of correlation between the variables the scheme proposed by M. Sobczyk (1998) was used. According to this scheme a correlation between the two characteristics is undetermined if $r_{x y} \leq 0,3$, average if $0,3 \leq r_{x y} \leq 0,5$ and strong if $r_{x y}>0,5$.

Figure 1: The distribution of answers to questions about $(\mathrm{H})$ involvement of employees, (I) the number of problems encountered and $(K)$ the amount of grassroots initiatives in the context of the implementation of the company's intellectual capital management mechanisms

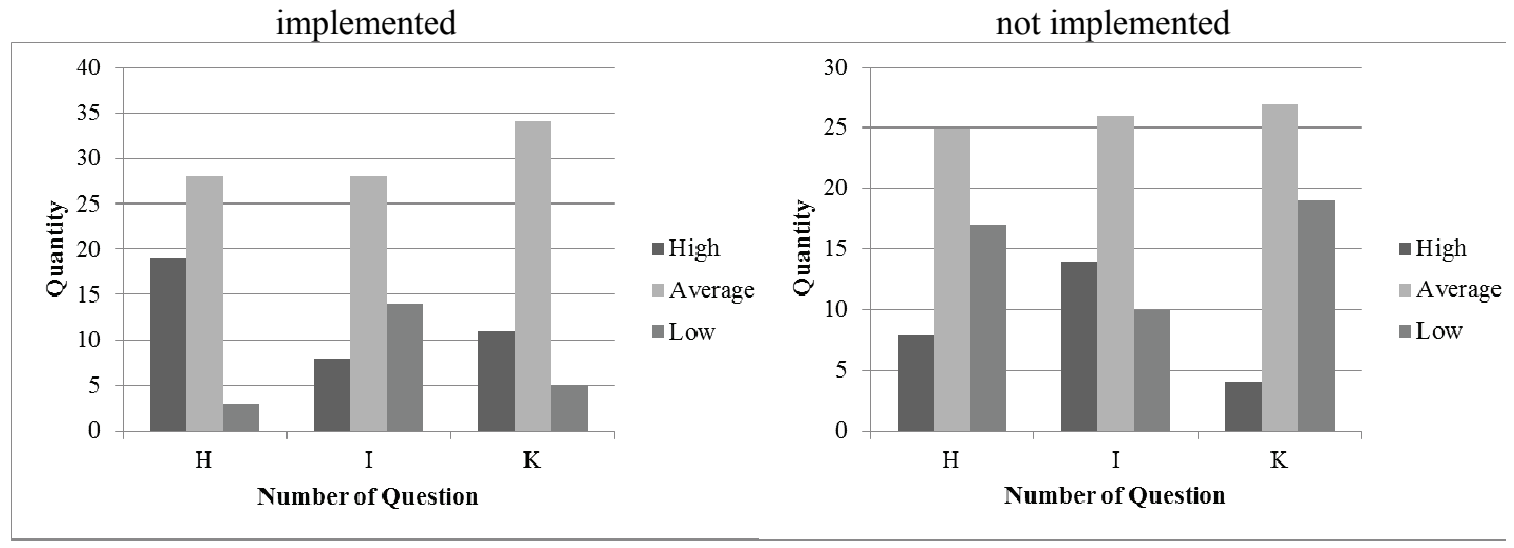

Source: own studies

Analysis of relationships between the analyzed aspects and selected strategic factors allowed to identify additional dependencies (Table 1). Most of the observed relationships was related to the size of the company and its development stage (age). The type of business, as well as the attractiveness of the sector does not lead to clear results. 
Table 1: Most important relationhip identified in the research

\begin{tabular}{|c|c|c|c|c|}
\hline No. & Company size & $\begin{array}{c}\text { Age of the } \\
\text { company }\end{array}$ & Business type & $\begin{array}{c}\text { The } \\
\text { attractiveness } \\
\text { of the market }\end{array}$ \\
\hline A & pronounced $(0.53)$ & undetermined & undetermined & undetermined \\
\hline B & pronounced $(0.54)$ & undetermined & average $(0.49)$ & average $(0.48)$ \\
\hline C & undetermined & undetermined & undetermined & undetermined \\
\hline D & undetermined & undetermined & undetermined & undetermined \\
\hline E & undetermined & undetermined & undetermined & undetermined \\
\hline F & average $(0.48)$ & average $(0.37)$ & undetermined & undetermined \\
\hline G & undetermined & undetermined & undetermined & undetermined \\
\hline H & average $(0.36)$ & undetermined & undetermined & undetermined \\
\hline I & average $(0.44)$ & average $(0.36)$ & undetermined & undetermined \\
\hline J & average $(0.40)$ & average $(0.36)$ & undetermined & undetermined \\
\hline K & undetermined & average $(0.34)$ & undetermined & undetermined \\
\hline$*$ Question numbers in accordance with previously described questionnaire & & \multicolumn{2}{l}{ Source: own research } &
\end{tabular}

Figure 2 shows the distribution of answers to questions concerning the type of activities undertaken by the company. Small companies in particular focus on organization of research programs and determining of their own human capital capabilities. For large enterprises the most important activities were: the development of research programs, analysis of the impact of innovation on the employment structure, defining enterprise's opportunities related to human capital. Companies in this group least often pointed: analysis of market trends and solutions used by competitors.

Many relationships have been identified in the context of the sources of knowledge (Figure 3). From the point of view of company size only customers and competitors were indicated as the most important source in all groups of enterprises. In the context of other responses (universities, research institutions, research - development units, suppliers) significant divergence in distribution of results was observed. Among production companies research - development units were indicated more frequently. 
Prusak, R.

Figure 2: Summary of activities undertaken by enterprises

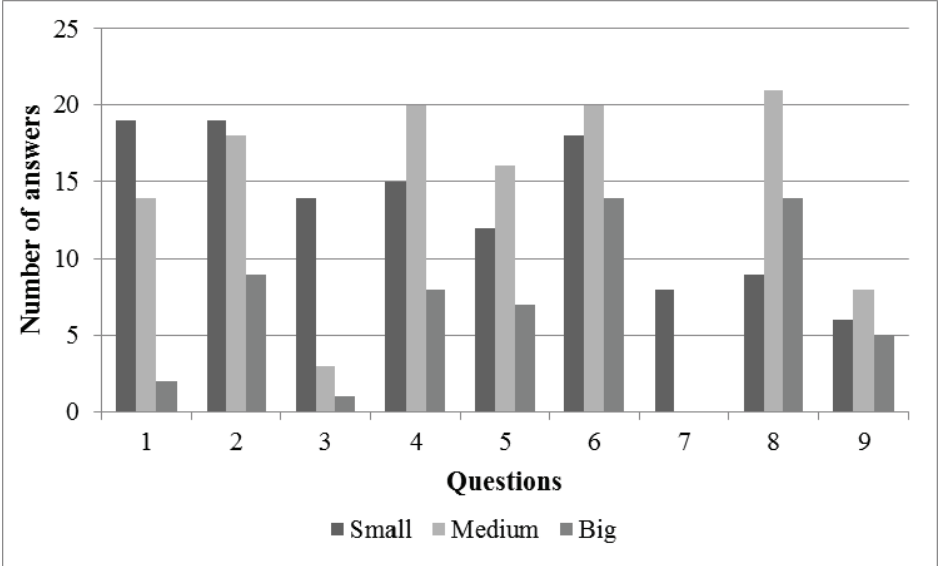

Questions: 1. Organization of research programs, 2. Determination of their own human capital capabilities, 3. Examination of the impact of innovations on the employment structure,

4. undertaking initiatives expected to shorten the innovation cycle, 5. Analysis of the technological base in the context of the planned changes, 6 . Analysis of the incurred financial outlays, 7. Determination of possibilities for strategic alliances, 8 . analyses of market trends and solutions used by the competitors, 9. Others.

Source: own research

Figure 3: Summary of sources of knowledge according to (a) company size, (b) business type, (c) the attractiveness of the market

a)

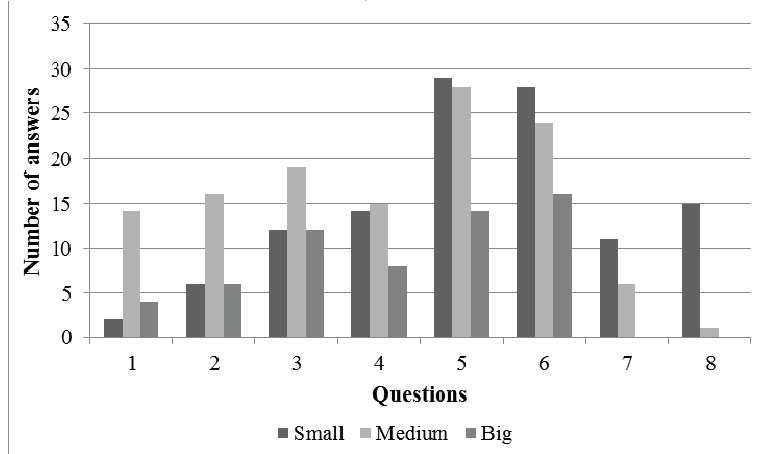

b)

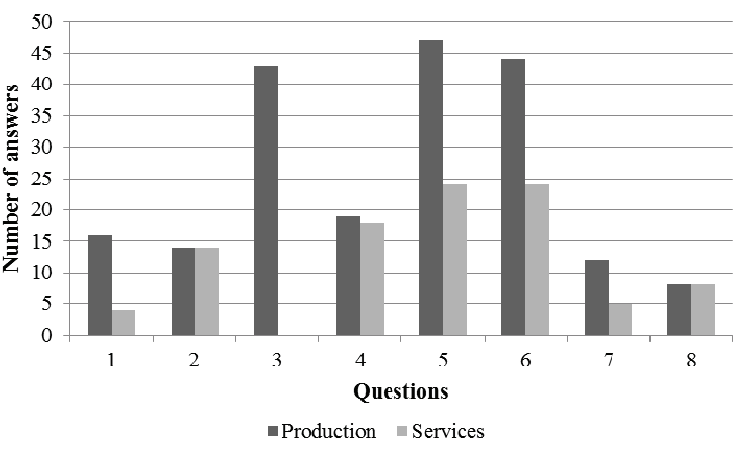

c)

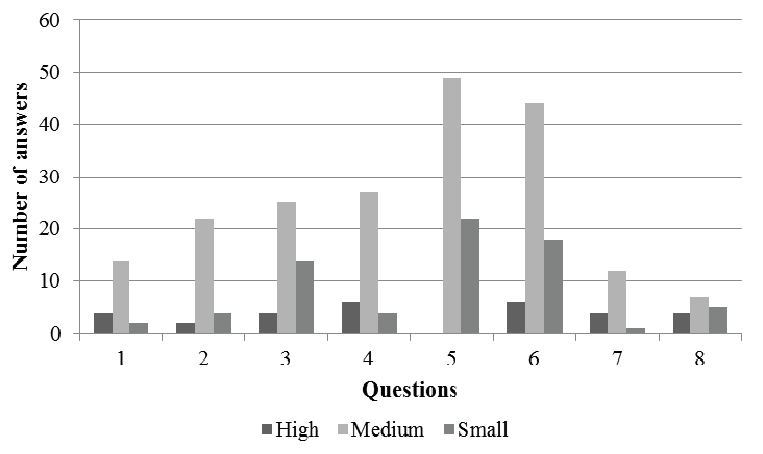

Questions: 1. Universities, 2. Research institutions, 3. Research units, 4. Suppliers, 5.

Customers, 6. Competitors, 7. Seminars, conferences, 8. Other.

Source: own research 
Interesting data distribution was observed in the analysis of the economic effects of implemented innovation (Figure 4). The effects in small and medium-sized enterprises often were consistent with the plan or exceed the earlier assumptions. In large enterprises declared the results were often lower than planned. Analysis of the results in the context of the stage of development of the company (its age) showed that young companies have more problems to get planned economic effects. This may indicate that the proper development and implementation of innovations require prior experience in the implementation of these - or similar - processes.

The size of the company also had an impact on such factors as: involvement of employees, the number of encountered problems, and the time spent to solve problems. In all these aspects of higher results were declared by small and medium-sized enterprises.

Also interesting was the distribution of responses related to number of grassroots initiatives in the context of the development stage of enterprises. Developing companies declared a larger number of these types of elements. In the group of mature companies - those figures were significantly lower.

Figure 4: Summary of economic effects according to (a) company size, (b) age of company

a)

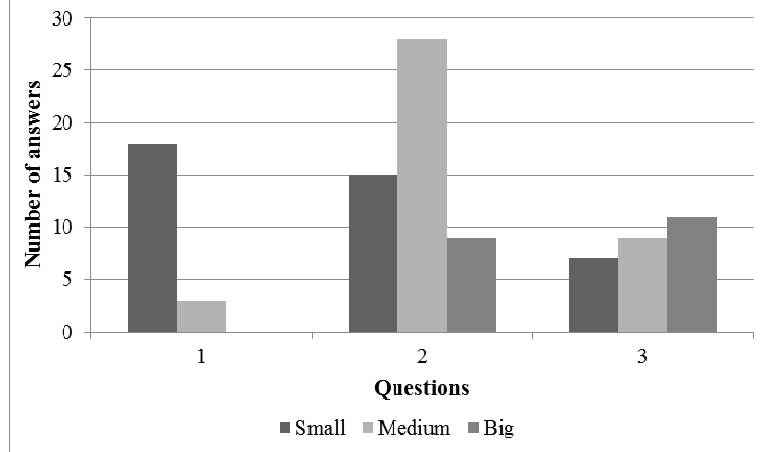

b)

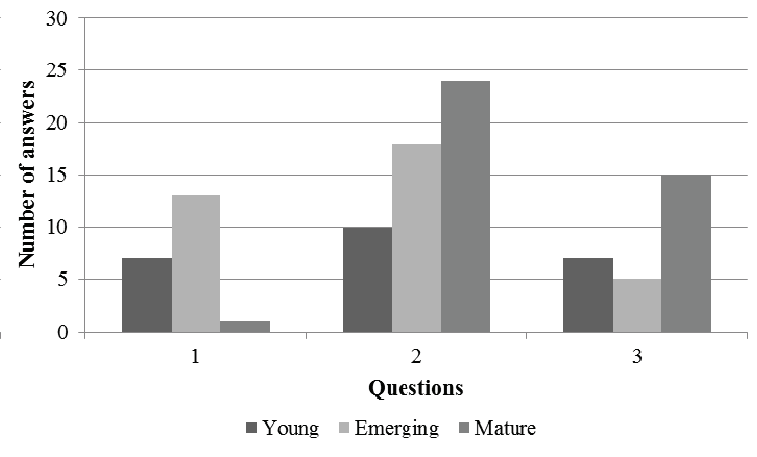

Questions: 1. Above plans, 2. As planned, 3. Below plans.

Source: own studies

\section{Conclusions}

Identified relationships allow for conclusions about the basic relationships between intellectual capital management and intensity and efficiency of innovation processes. The introduction of mechanisms of intellectual capital management directs the company to take better advantage of intangible which are an important element of building a competitive advantage in today's market. By placing greater emphasis on knowledge, its acquisition, development and distribution it is possible to make better use of the potential accumulated in the human resources. People with their professional and personal experience are the only internal source of innovation. 
Analysis revealed the existence of certain relations in the examined areas. Certainly, they require confirmation in a larger research sample. Very interesting are relationships between the fact of implementing intellectual capital management mechanisms and important aspects of the innovation process, such as: level of employee involvement in the undertaken initiatives, number of grassroots ideas and concepts that may become the seeds of new solutions, number of problems encountered in process of development and implementation of innovations.

Additional strategic criteria used in the research also allow identifying interesting phenomena and trends. Above all, the relatively small impact of the business type and the level of market attractiveness. It would seem that - especially - the first factor should have bigger impact on the diversity of the results. Undeniably the greatest impact on the distribution of data has a size of enterprise and stage of development of enterprises.

Intellectual capital management is a process that requires a broad, interdisciplinary approach. The possibilities for its development lie virtually in all areas of the enterprise's operation and all resources possessed by it. The issues related to intellectual capital require therefore a comprehensive approach to be taken, which will significantly increase the level of complexity of the problem, but will also enable the enterprise to attain a greater likelihood of utilizing the potential that it has.

Intellectual capital - and its relationship with the different areas of business management - still requires intensive research. The potential in this area is very large and can lead to getting the distinct strategic advantages. Managerial staff often does not try to collect all the resources required to conduct the business activity within the organization, focusing rather on maintaining control only on the strategic resources. Material resources more easily lend themselves to observation, measurement and analysis. An enterprise has also much greater possibilities of acquiring or selling them. Immaterial assets, related primarily with people, have no physical or financial form; nevertheless, they are an important element of the enterprise's functioning and building competitive advantage. In addition, most of these resources cannot be purchased, but must be created and developed.

\section{References}

1. Begg D., Fisher S., Dornbush R. (1997): Makroekonomia, PWE, Warszawa, p. 341.

2. Drucker P. (1992): Innowacje i przedsiębiorczość. Praktyka i zasady, PWE, Warszawa, p.42.

3. Fitz-Enz J.: Rentowność inwestycji w kapitał ludzki, Oficyna Ekonomiczna, Kraków 2001, s. 23-24.

4. Pobrotyn A. (2012): Znaczenie kapitału intelektualnego w zarządzaniu przedsiębiorstwem, ,Acta Scientifica Academiae Ostroviensis”, 1/2012, p. 121

5. Rindova V.P., Fomburn CH.J. (1999): Constructive Competitive Advantage: The Role of Firm - Constituent Interaction, ,, Strategic Management Journal”, 8/99, p. 691 
6. Schumpeter J. (1960): Teoria wzrostu gospodarczego, Wydawnictwo Naukowe PWN, Warszawa, p. 104.

7. Skrzypek E. (1999): Wpływ zarządzania wiedzą na jakość, „,Problemy Jakości”, no 11,1999, p.5.

8. Sobczyk M. (1998):" Statystyka, Wydawnictwo Naukowe PWN, Warszawa, p. 209.

9. Szara K., Pierścieniak A. (2007): Kapitał intelektualny jako obszar konkurencji przedsiębiorstw (wybrane aspekty teoretyczne), in: M.G. Woźniak (ed.) 2007, Nierówności społeczne a wzrost gospodarczy. Gospodarka oparta na wiedzy, Uniwersytet Rzeszowski, Rzeszów, p 255. 